\title{
The Determinants of Islamic and Conventional Banks Profitability in the GCC Region
}

\author{
Bassam Omar Ali Jaara $^{1}$, Mohammad A. AL-Dahiyat ${ }^{1}$ \& Ismail AL-Takryty ${ }^{1}$ \\ ${ }^{1}$ Business School, Al Ahliyya Amman University, Amman, Jordan \\ Correspondence: Bassam Omar Ali Jaara, Business School, Al Ahliyya Amman University, Amman, Jordan. Tel: \\ 962-5-350-0211/17. E-mail: b.jaara@ammanu.edu.jo
}

Received: December 4, 2020

Accepted: December 30, 2020

Online Published: January 11, 2021

doi:10.5430/ijfr.v12n3p78

URL: https://doi.org/10.5430/ijfr.v12n3p78

\begin{abstract}
The purpose of this study is to examine the factors affecting the profitability levels of commercial banks whether Islamic and non-Islamic over the period 2000-2018, to suggest ways to enhance the Islamic and non-Islamic banks profitability levels' in the GCC countries. This research employed Bivariate analysis and panel regression in the investigation process. The study employed return on assets ratio as a proxy for banks profitability. The study found out that conventional banks are more efficient than Islamic banks in terms of profitability levels. There are substantial variances between both Islamic and conventional banks in terms of the determinants of banks' profitability. It is found that $89 \%$ of the Islamic bank's profitability and $85 \%$ of conventional banks profitability influenced by bank size, market to book value, capital ratio, cash to assets, gross domestic product GDP, GDP growth, and inflation.
\end{abstract}

Keywords: profitability levels, Islamic banks, conventional banks, microeconomic and macroeconomic variables

\section{Background}

Islamic bank's funding tools were established to achieve the same financial purposes as conventional banks' funding tools but within the principles of Islamic sharia rules. Consequently, Islamic laws applied to finance are established into two key values; initially is forbidden for Islamic banks to charge interest, which is known as "Riba". The second major principle it prohibited for Islamic institutions and individuals to participate in activities and economic transactions that are banned in the Islamic belief (Ariffin, 2012).

Consequently, Islamic laws prevent Muslims carry out the financial transactions on the interest rate, but it does not prohibit capital gain (Miah et al 2018). This role has revealed the significance of examining the factors affecting the profitability levels of Islamic and non-Islamic commercial banks. To a certain degree, Ariffin (2012) argues that Islamic banks do not have sufficient financial tools to help them obtain short-term funding, it is not allowed for the Islamic banking system to use the money market tools employed by their conventional counterparts.

On the contrary, Mohammad, Mohammad, and Samsudin (2013) claim that insufficient financial tools influence the Islamic banks profitability levels such as the limited number of available Islamic money market tools and the interbank markets that can influence the Islamic bank's liquidity levels. Moreover, the existing financial instruments, which employed in the secondary market, are insufficient. Such as, bonds and treasury bills which are extensively used in conventional banks are not an option for the Islamic banking system.

Studying the banks' profitability determinants is a vital research area, as effective management in the bank's resource improve the profitability and financial stability of banks whether Islamic or conventional. Moreover, since the Islamic banking system is a period of dramatic growth, then Islamic banks must face this growth concentrating on profitability determinants. Nevertheless, investigating the factors influencing the profitability levels of both types of banks' is not something new; however, the previous academic studies have not concentrated enough to suggest methods to progress the Islamic and conventional banks profitability.

Importantly, the academic literature has focused on particular countries when examining the factors affecting the Islamic and conventional banks profitability, or when examining the influence of economic and accounting data on banks' profitability. A limited number of previous academic research examined the factors affecting the Islamic and conventional banks profitability employing a cross-country sample of economic and accounting data. Importantly. 
This empirical study interest is in the extent to which Islamic and conventional banks can arrange the management of the financial affairs to sustain and enhance the profitability levels.

\section{Literature Review}

Islamic banks showed notable development in the last decades. However, commercial banks aim to increase their net profit, to increase the wealth of the shareholders. Importantly, the banking system exposes to internal and external types of risks, which affect their profitability levels. Consequently, commercial banks need to shed the light on their internal and external environments, to enhance profitability. Whereby, the levels of banks profitability are considered a vital discussed research area since it reveals the whole banking system.

However, recent academic studies such as (Miah 2017; Noman 2015; Asadullah 2017 and Nur et al 2018) have argued that the factors influencing the profitability levels can be classified into two types; internal and external factors that should together deliver a statistical significance tool to investigate the bank's profitability

\subsection{The Origin and Development of the Islamic Banking System}

Barclays bank in Cairo considered the first bank established in the Middle East region in the 1890s. However, the establishment of this bank has raised the significance of the conventional banking industry in Muslim countries and extended to the Arab region. In the same context, the theoretical base of the conventional banking system is founded on interest charges that are banned in the Islamic Sharia Laws. The growth of the conventional banking system in the Muslim countries have raised the significance of creating a financial system consistent with the Islamic Sharia laws (Hanif and Iqbal, 2010).

Importantly, throughout the period 1930-1950, Islamic scholars argued the reason for preventing the concept of interest charges in the conventional banking system and endeavored to propose additional financial system work under the notion of profit and loss sharing transactions (PLS) (IFSB, 2007).

Consequently, the foundation of the first Islamic bank "bank Mit Ghamar 1963" has raised the significance for Muslims to perform investment or borrow money under the notion of Islamic Sharia laws (Iqbal and Molyneux, 2005). In the same regard, Wilson (2007) argued that Dubai Islamic bank considered the first Islamic commercial bank in 1973. This is followed by Kuwait finance house, Bahrain Islamic Bank, Jordan Islamic bank, Al Rajhi Bank. In addition, the first Islamic insurance system was founded in 1979.

Notably; the period of the 80s has witnessed that tow Islamic countries "Sudan \& Iran" have changed their financial system from capitalism into Islamic System (Wilson, 2007; Iqbal and Molyneux, 2005). Moreover, many Islamic financial institutions started their investment in Europe and Muslim countries; whereby the United Kingdom considered being the main access for the Islamic banking system to Europe and the USA.

\subsection{The Wisdom Behind Prohibiting Interest Transactions "Riba"}

Islamic banks philosophy is based on combining two main standards including employing the concept of profit and loss distribution and the prevention of charging interest (Gait \& Worthington, 2008). However, many previous academic studies have stated that Islamic banks forbid interest charges that increase the loan payments, which since if borrower exposed to financial loss then the interest payments will lead to an increase in the borrower expenditures, which will increase the lenders profit. Consequently, the principles of Islamic banks prevent interest transactions because these payments are considered as unfair to the borrower (Khan and Ahmed, 2001).

\subsection{Comparison of Islamic and Conventional Banking}

Albertazzi and Gambactora (2010) argued that Islamic banks implement their investments under the notion of PLS. this kind of investment obliges the investor and to participate in the investment and share the loss or profit under agreed ratio. In contrast, conventional banks considered financial intermediation institute work as a broker between the borrower and the lender. Therefore, the profit is generated through the difference between the rate of interest that has been offered to the depositor and the interest charged to the borrower

Consequently, Ali (2010) claim that the principles of Islamic banks are based on equitable wealth distribution, integrity, justice, fairness, and trust. Besides, the Islamic banking industry inspires social justice through forbidding financial investment that leads to injustice and exploitation.

Notably, both conventional and Islamic banks considered as financial organizations that aim to raise the net profit and increase the shareholder's wealth. However, the distinctions appear in the applied instruments to fund their financial transactions. Thus, this significant difference between both types of banks led to shedding light on investigating the profitability determinants of Islamic conventional banks. 


\subsection{Empirical Studies on the Factors Influencing the Profitability in Both the Islamic and Conventional Banks}

The main aim of any financial institute is to raise the net income in order to increase the shareholder's wealth. Many previous studies have introduced detailed suggestion of the profitability determinants in both types of banks. For instance, Heffernan and Fu (2009) investigated the determinants of 76 conventional banks' profitability in China during 1999-2006 by employing panel regression, the empirical findings showed that the GDP rate revealed a positive significant finding on the profitability levels, whereby countries with a strong economic situation can reduce credit losses and enhance the quality of loans, this will contribute to an increase in the profitability levels. However, countries with an inefficient economy can decrease the credit levels by individuals and investors; this will decrease the profitability levels.

Harbi (2019) examined the profitability levels of 686 conventional banks in 52 developing countries during 1989-2008, by using fixed effect model. The findings of this research showed that off balance sheet events, interest rate, loans, GDP growth and foreign ownership will enhance conventional banks profitability. On the contrary, bank size, and GDP per capita have an insignificant impact on banks profitability.

In another recent study, Hidayat \& Sakiti (2020) studied the influence of Oil prices on Islamic banks performance, the Dynamic GMM model on 81 Islamic banks during the period 2006-2015. The empirical results revealed oil price has an insignificant impact on the Islamic banks profitability, since the results showed that $46 \%$ to $60 \%$ of the profitability of Islamic banks respond indirectly to the fluctuations in oil prices. In the same regard, Aslam \& Haron (2020) employed GLS model to investigate the performance of 20 Pakistani banks throughout 2006-2015. The results of this research revealed that Islamic and conventional banks affected strongly by board size, whereas there is an insignificant relationship between banks performance and board committees. In the same context,

In another recent study, Imane (2020) investigated the Islamic banks profitability levels by using the fixed effect model on 10 Islamic banks in Jordan, KSA, UAE, and Bahrain during the period 2008-2018. The results showed that exchange rate, liquidity risk, inflation, credit risk and GDP showed significant influence on the Islamic banks profitability. In the same regard, Nur et al (2018) employed panel regression on 16 Malaysian Islamic banks during 2010-2016.The researcher employed ROA to proxy the financial performance, however the findings revealed that the liquidity levels and assets management ratio has a positive influence on the bank's performance, whereas capital adequacy revealed an insignificant impact on the Islamic bank's financial performance.

Similarly. Muhammad (2018) shed the light on the Islamic banks profitability levels in Pakistan throughout 2007-2016 using panel regression techniques. The findings showed that Islamic banks profitability is affected significantly by market size and payout ratio during the period of study. However, a substantial number of previous studies investigated the correlation between profitability levels and the inflation rate. For example, Molyneux and Thornton (1992) stated that the inflation rate influence negatively on the Islamic banks profitability. In contrast, Perry (1992) analyzed the influence of the inflation rate on the profitability levels of conventional bank's. The findings revealed that inflation is expected then the interest rate can be adjusted and this is will reflect positively on the profitability levels. In contrast, if the bank management cannot expect the inflation rate then this is will show a negative influence on the bank's profitability levels.

In the same context, Mohamad, et al (2018) studied the relationship between financial risk and Islamic banks profitability by employing regression analysis on 17 Islamic banks in Malaysia during 1994-2015. The results suggest that Islamic banks profitability levels are affected strongly by liquidity ratio, financing loss, and capital ratio. Besides, the interbank rate, growth in GDP, the unemployment rate has a significant impact on the Islamic banks profitability. In another recent study, Nurhafiza and Tajul (2018) employed the (GMM) to observe the profitability margin of the commercial banks whether Islamic or non-Islamic during 2006-2013. The results showed that Islamic banks are significantly influenced by the inflation rate, size level, overhead costs, and regulatory quality.

Further researches have applied panel regression to explore the factors affecting profitability levels of both conventional and Islamic banks. For example, Tariq (2018) employed fixed effect panel regression to study the profitability determinants of 26 conventional banks and 42 Islamic in the MENA countries during 2006-2016. The outcomes revealed that bank size, deposit to asset ratio, equity to assets have a negative influence on the conventional banks, whereas it showed a positive influence on the Islamic banks. On the contrary, securities to assets showed a negative impact on the Islamic banks profitability levels, whereby, securities to assets showed a positive influence on conventional banks.

Importantly, prior academic researchers have not concentrated enough to suggest ways to enhance the profitability levels of both kinds of banks. This is the aim of the research to explore the factors affecting the Islamic and 
conventional bank's profitability. Likewise, limited previous studies have observed the profitability determinants of both types of banks using empirical population sampling of economic and accounting statistics in the GCC.

\section{Methodology}

This research studies the determinants of banks' profitability levels whether Islamic or conventional by applying a population sample of both types of banks. The sample comprises all countries in the GCC region throughout 2000-2018. However, following a similar research methodology of Tariq (2018), Muhammad (2018) and Helal (2017). All listed banks in the GCC region during 2000-2018 were employed, in order to compare and explore the factors affecting the profitability of both types of banks. This study investigates the influence of several independent factors on the dependent factors (profitability levels).

The study employed F-testing, (R2) and T-testing, to test the rationality of the panel regression outcomes, however the F-test was applied to investigate the significance level to the overall model, (R2) were employed to determine the model goodness of fit. In addition, a T-test was applied to analyze the significance level for each variable respectively (Wooldridge, 2012).

The dependent factor ROAi,j,t, which shows the profitability level for bank I in country $\mathrm{J}$ at time t. the study employed return on assets to proxy bank profitability levels, which is known as the net income over banks total assets (Pratt, 2010). However, the population sampling of both types of banks covers the period 2000-2018 and include (57) Islamic banks and (73) conventional banks.

\subsection{Research Hypothesis}

Relying on a panel regression analysis, this empirical study stipulates three different research hypotheses that could enhance the profitability levels of both types of banks. However, the following research hypotheses were suggested to enhance the profitability levels of both conventional and Islamic banks in the GCC region

H0: there is an insignificant difference in the profitability levels between Islamic and conventional banks

H1: there is a significant variance in the profitability level between Islamic and conventional banks

The first research hypothesis is directly associated with the profitability level. It suggests that non-Islamic banks considered to be more profitable, which is due to that they can invest their assets ineffective financial instruments more efficiently than Islamic banks. Generally, Islamic banks lack the elasticity of their conventional counterparts when seeking short-term funding it is banned for the Islamic sector to use the money market tools applied by non-Islamic banks. Notably, the return on assets ratio is employed as a proxy to investigate the profitability level in both types of banks. Importantly, these measurements extensively employed in academic studies, which is known as the net profit over total assets.

H0: internal variable had an insignificant effect on the bank profitability levels

H1: internal variable had a significant influence on the bank's profitability levels

The second research hypothesis is directly associated with the internal bank strategies for banks' profitability levels. The assumption is that the internal environment contributing strongly to determine the profitability levels of the commercial banks whether Islamic or non-Islamic types of banks. Notably, four different variables were used to measure the influence of the internal variables on the profitability levels of conventional and Islamic banks.

I. The natural logarithm of the banks total assets is employed as a proxy to examine the bank size on the profitability levels.

II. Market value over the book value is employed as a proxy to examine growth opportunity in the future for both type of banks

III. Cash to assets is applied as a proxy to measure the percentage of the available cash in both type of banks

H0: the external economic variables had an insignificant influence on the bank's profitability

H1: the external economic variables had a significant influence on the bank's profitability

The exterior economic variables that were used in this empirical analysis where the GDP growth, (GDP), and inflation. Nevertheless, the assumption is that the macroeconomic variable can enhance the profitability of Islamic and conventional banks. In the same regard, to enhance the profitability levels of both type of banks, the suggested model is founded on the internal and exterior variables that can be considered as the determinants of profitability levels of conventional and Islamic banks'.

Since the factor interval ROAi,j,t considered as the dependent variable, that evaluates profitability level for a bank I 
in country $\mathrm{j}$ at time $\mathrm{t}$, this study applied random, pooled and fixed effect methods to examine the panel data. Jaara et al (2017) claim that this tool is suitable for time series and cross-sectional, the main advantage of panel methodology is that panel methodology controls individual heterogeneity.

\subsection{Model Specification}

To progress the profitability levels of both conventional and Islamic banks, the factors developed in this empirical study are derived from previous academic studies that examined the Islamic banks and conventional banks, which are based on the internal variables and exterior variables, which have a noteworthy impact on the profitability determinants of conventional and Islamic banks'. The estimation of pooled, fixed and random regression is developed as follow:

$$
\begin{aligned}
R O A_{i, j, t}= & B_{0}+B_{1} \operatorname{SIZE}+B_{2} M B_{i, j, t}+B_{3} \text { CAPITAL RATIO }_{j, t}+B_{4} C F / T A_{i, j, t}+B_{5} \text { GROWTH GDP }_{i, j, t}+ \\
& B_{6} \text { INFLATIN }_{i, j, t}+B_{7} G D P_{i, j, t}+\varepsilon
\end{aligned}
$$

Table 1. Variables description

\begin{tabular}{ll}
\hline variables & Definition \\
\hline $\mathrm{B}_{-} 0$ & Intercept coefficient \\
$\mathrm{B}_{1}, \mathrm{~B}_{2}, \mathrm{~B}_{4}, \mathrm{~B}_{5} \mathrm{~B}_{6} \mathrm{~B}_{7}$ & Coefficient of the independent variables \\
$\mathrm{B}_{3}$ & Coefficient of the control Variable \\
$\mathrm{SIZE}$ & the natural logarithm of total assets \\
$\mathrm{B}-\mathrm{M}$ & Book value over market value \\
Capital ratio & Equity to total assets \\
CF/TA & is the cash over tot assets \\
Growth GDP & The annual growth in the gross demotic product. \\
Inflation & The annual inflation rate. \\
GDP & Gross Demotic Products. \\
& error term, which is uncorrelated with all variables \\
\hline
\end{tabular}

The factors established in this academic study is derived from previous researches on the conventional and Islamic banking system that is based on internal factors and exterior variables, which have a significant effect on the determinants of conventional and Islamic banks' profitability. Consequently, the demonstration of dependent and independent factors that employed in the panel regression are illustrated as follows

I. ROAi, , t is measured by net profit over the total assets.

II. Size: microeconomic variable is measured as the total assets natural logarithm.

III. Market to book value is measured by the market price over the book value.

IV. The capital ratio is measured by equity to total assets.

V. Cash to total assets: this ratio is measured by the bank available cash over total assets.

VI. Gross domestic product (GDP): this variable is employed as a measurement of the influence of external factors on the banks profitability. In the same regard, the GDP can be considered as an index for the demand of banks services such as; money supply and loan extension.

VII. Growth in GDP investigates how fast the country's economy is growing to shed light on the rise in the adjusted inflation market value of services and goods produced by a country's economy.

VIII. Inflation rate: is a quantitative evaluation of the rate of price level of selected services and goods in the country during a time. It is the constant increase in prices where a currency buys less than it did in previous time.

\section{Data Analysis}

\subsection{Background}

The recent economic fluctuations have influenced the profitability level of the banking industry worldwide. There 
has been a growing consent that there is an excessive requirement for an additional bank system, whereby the Islamic banking system can be an effective substitute financial system, however, many researchers and economics have argued the significance of enhancing the financial stability and profitability levels of the banking system. For instance; Basel (2011) published the framework for post-crisis reform, it shed the light on the lacks of the pre-crisis regulatory framework and introduces a supervisory basis for an effective bank system that contributes to developing the real economy.

Consequently, this section explores the determinants of Islamic and non-Islamic commercial banks' profitability by examining several variables during the period 2000-2018. For instance, market to book value examines the asset quality, a capital ratio that examines the banks' capital adequacy, the bank's total assets (size) that provide significant insight regarding the success of Islamic banks compared with conventional banks. In the same regard, several controlling variables are significant for examining the profitability determinants of Islamic and conventional banks'. For instance, the macroeconomic controlling variables, such as; the GDP annual growth rate, (GDP) and the annual inflation rate.

\subsection{Descriptive Analysis}

Table 2. Bivariate analysis

\begin{tabular}{|c|c|c|c|c|c|c|}
\hline \multicolumn{7}{|c|}{ Independent Samples Test } \\
\hline & & $\mathrm{N}$ & Mean & Mean Difference & $\begin{array}{l}\text { Std. Error } \\
\text { Difference }\end{array}$ & Sig. (2-tailed) \\
\hline \multirow{2}{*}{ ROA } & Islamic & 310 & .019 & \multirow{2}{*}{-.001} & \multirow{2}{*}{.001} & \multirow{2}{*}{.236} \\
\hline & Conventional & 648 & .020 & & & \\
\hline \multirow{2}{*}{ Size } & Islamic & 325 & 9.794 & \multirow{2}{*}{-.212} & \multirow{2}{*}{.037} & \multirow{2}{*}{.000} \\
\hline & Conventional & 664 & 10.006 & & & \\
\hline \multirow{2}{*}{ M-B-Ratio } & Islamic & 307 & 2.040 & \multirow{2}{*}{.203} & \multirow{2}{*}{.109} & \multirow{2}{*}{.063} \\
\hline & Conventional & 618 & 1.837 & & & \\
\hline \multirow{2}{*}{$\begin{array}{c}\text { Capital } \\
\text { Ratio }\end{array}$} & Islamic & 325 & .170 & \multirow{2}{*}{.028} & \multirow{2}{*}{.006} & \multirow{2}{*}{.000} \\
\hline & Conventional & 664 & .142 & & & \\
\hline \multirow{2}{*}{$\mathrm{CF} / \mathrm{TA}$} & Islamic & 312 & .009 & \multirow{2}{*}{-.001} & \multirow{2}{*}{.001} & \multirow{2}{*}{.220} \\
\hline & Conventional & 659 & .010 & & & \\
\hline
\end{tabular}

The above table shows that non-Islamic banks have better financial performance than their counterparts. For instance, the conventional banks return on assets (ROA) is $20 \%$ compared with $19 \%$ for Islamic banks, which is due to that the Islamic banking system has different principles than conventional banking systems. Notably, the philosophy of the Islamic banks is based on profit and loss sharing transactions (PLS), which adhere the Islamic bank to participate in the risk with the depositors and borrowers, in order to contribute to the community.

On the contrary, the principles of conventional banks are founded on the interest bases, which shed the light on that conventional banks aim to maximize the shareholder's wealth by increasing the levels of investment return. Hanif (2011) claims that this is because that the concept of PLS transactions allows both parties of the agreement to contribute in the investment decision and trading process. However, this might contributes to reducing the levels of financial risk.

In the same regard, since conventional banks showed a better return on assets than Islamic banks, these findings revealed the effectiveness of conventional banks to manage their assets efficiently compared to the Islamic banking system. Notably, commercial banks whether Islamic or commercial offer loans on long-term basses to the borrower on the short-term deposits, which can be withdrawn at any time. Therefore, this leads to assets liability mismatch, which may lead to liquidity risk problems and expose the banks to bankruptcy problems.

In the same context, the average Islamic bank size is smaller than the non-Islamic commercial banking system. Whereby, the mean of total assets of Islamic banks is $\$ 9.794$ compared with $\$ 10.006$ for the conventional banks, which is due to that Islamic banks is a new financial system, which started its operations by the beginning of the 70s, 
and has not got the opportunities to expand as their counterparts. Consequently, the findings of the descriptive table indicated that the Islamic banks could be considered more stable and safer than the non-Islamic commercial banking system

Likewise, the above table reveals that Islamic banking system has a better market to book value ratio than conventional banking system, whereby the market to book value for Islamic banks is (2.04) and (1.837) for conventional banks. Notably, this indicates that Islamic banks have better growth opportunities in the future by (20\%) than conventional banks, which may lead to better profitability levels for Islamic banks compared to non-Islamic banks.

Importantly, there are cost benefits the two kinds of banks, since the financial stability of the Islamic bank seems to be more efficient than conventional banks, even if the profitability levels of conventional banks are higher than Islamic banks. For instance, the above table shows that the findings of standard error for the Islamic banking system are lower in magnitude than the conventional banking system, which shed the light on that there is a less extreme distribution for the Islamic banks.

In the same regard, regarding the findings of the above table, Islamic banks are more effective in terms of capital adequacy ratio than conventional banks. Likewise, this is an important indicator for Islamic and conventional banks, since several theoretical models propose that commercial banks are stimulated to put more equity capital in the investments, to reduce several types of risks such as moral hazard problems.

Moreover, banks with large size of assets incline to gamble with the depositor's money since there is an implicit bailout guarantee. For instance, many cases have occurred during the recent global financial rescission and several banks have to be bailout through using the money of taxpayers. Notably, this is indicated to that Islamic banks have more capital buffer than conventional banks, which give the Islamic banks more solvency and contribute to helping Islamic banks to survive any financial distress.

However, this is indicated that Islamic banks seem to be less risky than non-Islamic banks. Whereby, there are several researchers (Gait \& Worthington, 2008; Sole (2007) and Okte (2010), argued that the concept of PLS transactions makes Islamic banks less exposed to financial risk compared to their counterparts. On the contrary, the conventional banks rely on the interest charges, to increase the bank's returns and maximize the shareholder's wealth.

Therefore, Islamic banking system can be considered as more efficient in having a capital buffer level than conventional banks. Consequently, there are several opportunities for conventional banks to improve their financial system through learning from the Islamic banking system.

Lastly, the findings of cash to total assets indicate that Islamic banks have $(0.009 \%)$ while conventional banks have $(0.01 \%)$. However, the following sections will show the light on the correlation analysis among the factors and the panel regression will provide an accurate view of the profitability determinants of both types of banks'.

\subsection{Correction Analysis}

Table 3. Correlation Matrix (Islamic banks)

\begin{tabular}{|c|c|c|c|c|c|c|c|c|}
\hline \multicolumn{9}{|c|}{ (Islamic Banks ) } \\
\hline & ROA & Size & M-B-Ratio & $\begin{array}{c}\text { Capital } \\
\text { Ratio }\end{array}$ & $\mathrm{CF} / \mathrm{TA}$ & $\begin{array}{c}\text { GDP } \\
\text { growth }\end{array}$ & Inflation & GDP \\
\hline ROA & 1 & & & & & & & \\
\hline Size & $-.137^{* *}$ & 1 & & & & & & \\
\hline M-B-Ratio & $.392^{* *}$ & -.067 & 1 & & & & & \\
\hline Capital Ratio & $.343^{* *}$ & $-.393^{* *}$ & -.078 & 1 & & & & \\
\hline CF/TA & $.675^{* *}$ & .034 & $.366^{* *}$ & $.165^{* *}$ & 1 & & & \\
\hline GDP growth & $.230^{* *}$ & $-.134^{* *}$ & $.219^{* *}$ & $.126^{* *}$ & $.228^{* *}$ & 1 & & \\
\hline Inflation & .002 & $.108^{* *}$ & .040 & -.012 & -.069 & $.210^{* *}$ & 1 & \\
\hline GDP & .031 & $.532^{* *}$ & .060 & -.004 & .014 & $-.108^{* *}$ & .073 & 1 \\
\hline
\end{tabular}


Bank size, which considered as a proxy for the Islamic banks' total assets presented a negative correlation with the majority of the factors in the statistical model, mainly it has a negative correlation with the measurement of return on assets, and it is noteworthy that banks size has negative correlation with the measures of the buffer capital as explained earlier. Notably, this indicates to that Islamic banks with big size of assets are less strict about increasing the optional reserve or the equity capital base, this can increase the opportunity of liquidity risk causes a panic-driven run.

The market to book value had a positive significant influence on the return on assets (ROA), which increase the growth opportunity for Islamic banks in the future. Likewise, the capital ratio showed a positive influence on the banks (ROA), in another word, any rise in the capital ratio will lead to an increase in the profitability level of the Islamic banking system

Also, the cash to assets ratio showed a positive relationship with the Islamic bank's profitability levels. Moreover, the growth GDP showed an insignificant positive correlation with the Islamic bank's profitability, in another word, constant growth in the country GDP will lead to improve and increase the profitability levels of Islamic banks

In addition, the inflation rate and GDP revealed a significant positive correlation with the Islamic bank's profitability levels. Whereby increasing the inflation rate and GDP leads to an increase in the loan levels, which may reflect positively on the bank's profitability, since commercial banks whether Islamic or non-Islamic work as a financial broker between the depositor and borrower but they are different in the way they fund their financial transaction.

Table 4. Correlation Matrix (Conventional banks)

\begin{tabular}{|c|c|c|c|c|c|c|c|c|}
\hline \multicolumn{9}{|c|}{ (Conventional banks) } \\
\hline & ROA & Size & M-B-Ratio & $\begin{array}{c}\text { Capital } \\
\text { Ratio }\end{array}$ & $\mathrm{CF} / \mathrm{TA}$ & $\begin{array}{l}\text { GDP } \\
\text { growth }\end{array}$ & Inflation & GDP \\
\hline ROA & 1 & & & & & & & \\
\hline Size & -0.0548 & 1 & & & & & & \\
\hline M-B-Ratio & $.379^{* *}$ & .021 & 1 & & & & & \\
\hline Capital Ratio & $.517^{* *}$ & $-.545^{* *}$ & .065 & 1 & & & & \\
\hline $\mathrm{CF} / \mathrm{TA}$ & $.746^{* *}$ & $.116^{*}$ & $.176^{* *}$ & $.198^{* * *}$ & 1 & & & \\
\hline GDP growth & $.399^{* *}$ & $-.202^{* *}$ & $.155^{* *}$ & $.261^{* *}$ & $.321^{* *}$ & 1 & & \\
\hline Inflation & $.177^{* *}$ & -0.0009 & .103 & $.197^{* * *}$ & .013 & $.254^{* *}$ & 1 & \\
\hline GDP & .007 & $.540^{* *}$ & $.167^{* *}$ & $-.116^{*}$ & $.129^{*}$ & $-.160^{* *}$ & .059 & 1 \\
\hline
\end{tabular}

**. Correlation is significant at the 0.01 level (2-tailed).

*. Correlation is significant at the 0.05 level (2-tailed).

The correlation test of the conventional banks revealed almost adverse findings to the Islamic banking sector. However, the bank size of the conventional banking sector revealed a negatively correlated with the ROA, capital ratio and inflation rate. Importantly, this may indicate that conventional banks with large size of assets may face problem in managing their assets efficiently to generate profit this is maybe due to the risky financial tools employed by conventional banks

In the same regard, the market to book value had a positive correlation on the conventional banks' return on assets (ROA), which increases the growth opportunity for conventional banks in the future. Likewise, the results showed that any increase in the capital ratio will lead to enhance the profitability level of conventional banks. Likewise, Cash to total assets showed a positive correlation with the conventional bank's profitability levels. On the contrary, GDP, growth in GDP, and inflation rate showed a positive significant influence on conventional banks' profitability.

\subsection{Regression Analysis}

This section applies panel regression analysis, to explore the profitability determinants in both Islamic and conventional banks' during 2000-2018. The panel regression includes three different types of regression analysis namely; fixed effect, pooled effect and random effect. Moreover, the Husman test will be applied, to determine the 
suitable model for the banks, whereas if the findings of the Husman test are insignificant then the random model is suitable to use than the fixed-effect model.

\subsubsection{Islamic Banks}

The following regression represents the outcomes of the explanatory factors, which affect the Islamic banks profitability levels, by applying three different regression models: pooled, random, and fixed.

Table 5. Regression Analysis (Islamic banks)

\begin{tabular}{ccccccc}
\hline & \multicolumn{5}{c}{ Islamic Banks } \\
\hline OLS & OLS & Random Effect & Random Effect & Fixed Effect & Fixed Effect \\
\hline No. abs & 296 & 296 & 296 & 296 & 296 & 296 \\
R-squared & 0.868 & 0.880 & & & 0.898 & 0.901 \\
Adjusted R-squared & 0.866 & 0.876 & & & 0.859 & 0.864 \\
F(5, 45606) & 381.841 & 262.276 & & & 99.155 & 90.507 \\
P-value(F) & 0.000 & 0.000 & & & 0.000 & 0.000 \\
\hline Const & -0.067 & -0.054 & -0.052 & -0.037 & -0.033 & 0.015 \\
& 0.000 & 0.000 & 0.000 & 0.007 & 0.023 & 0.553 \\
Size & 0.058 & 0.086 & 0.042 & 0.077 & 0.024 & 0.093 \\
& 0.000 & 0.000 & 0.000 & 0.000 & 0.087 & 0.003 \\
M-B-Ratio & 0.017 & 0.018 & 0.015 & 0.016 & 0.013 & 0.014 \\
& 0.000 & 0.000 & 0.000 & 0.000 & 0.000 & 0.000 \\
Capital Ratio & 0.080 & 0.086 & 0.086 & 0.088 & 0.089 & 0.095 \\
& 0.000 & 0.000 & 0.000 & 0.000 & 0.000 & 0.000 \\
CF/TA & 0.725 & 0.696 & 0.721 & 0.692 & 0.720 & 0.687 \\
GDP growth & 0.000 & 0.000 & 0.000 & 0.000 & 0.000 & 0.000 \\
Inflation & & 0.000 & & 0.000 & & 0.000 \\
GDP & & 0.004 & & 0.032 & 0.111
\end{tabular}

The above results reveal the findings of the Islamic banks regression analysis, whereby the dependent factor was the return on assets that is evaluated by the net profit over total assets. The applied tool in the regression model is an unbalanced panel regression that includes 57 Islamic banks.

Moreover, Green (2008) claims that the Hausman test can be employed to determine among random, pooled and fixed effect. Wherein the null hypothesis claims that the chosen regression model is fixed effect vs random effect vs pooled effect, which examines whether the regressors are correlated with the unique errors, since the random effect is consistent if the null hypothesis is accepted, and the random model is preferred. However, as the results of the Hausman test revealed insignificant findings, then the null hypothesis is accepted, and it concludes that random effect is preferred.

The t-test and f-test results reveal that the regression models are significant at a 5\% level, however the R2 is (89\%) and the adjusted R2 is $(85 \%)$. This means that this research determined $(89 \%)$ of the factors that affect the profitability levels of Islamic banks. In other words, $(85 \%)$ of the changes in the Islamic banks profitability levels 
occur because of fluctuations in the explanatory factors.

The above findings reveal the determinants of profitability factors on the Islamic banking system. Therefore, the above table showed that bank size has a significant influence on the return on assets (ROA). This refers to that banks with a large size of assets are more profitable than other banks with small size of assets. Notably, these results are identical to the theory of the Islamic banks, whereas Islamic Sharia laws adhere to Islamic banks to invest in assets instead of trading in money.

Consequently, the findings of the regression model showed similar results between conventional and Islamic banks, where the only difference between Islamic and conventional banks appeared in the descriptive analysis, which showed that the Islamic banking system, is more solvent than non-Islamic banks since the Islamic banking system have better measures for the buffer capital.

The market value to book value had a significant influence on the Islamic bank's profitability. In other words, an increase in the market price compared with the book value then there is a growth opportunity in the future. This means that the Islamic banks can offer good investments to their investors and depositors, which helps to increase the Islamic banks ability to increase their profit during the short and long run.

Notably, Islamic banks implement their financial transactions under the notion of profit and loss sharing transactions (PLS), whereby this kind of funding tools allows the investor and the Islamic bank to contribute to the venture transactions as if a financial loss occurred in the investment project, then the Islamic banks and the other partner in the contract will share the financial loss according to its shareholding in the capital.

Another explanatory variable that was employed in this research was the capital ratio. The findings of the regression showed that capital ratio has a significant positive influence on the Islamic bank's profitability. Notably, Islamic sharia principles prohibit the capital provider "bank" to charge interest, whereas it does not forbid gain on capital. Hence, the Islamic financial service board adheres to Islamic banks to put more equity capital in the investments. This will lead to reducing several types of risks such as financial losses and moral hazard.

Moreover, the cash to assets ratio showed a positive significant effect on the profitability, whereas increasing the percentage of cash to total assets will reduce the financial risks and will lead to an increase in Islamic bank's profitability. Also, expectations and trends in the volume of cash can serve as a source of liquidity, which will lead to growth in investment opportunities in the future. Chiefly, Islamic banks with a sufficient percentage of cash will increase the bank's ability to invest at a reasonable cost, which will enhance the profitability levels and decrease financial risks.

In the same context, the GDP rate and growth in the GDP are applied to investigate the influence of the country's economic situation on profitability levels. Notably, the outcomes of the regression showed that the country's GDP showed a significant positive impact on the profitability levels in the Islamic banks. Interestingly, this indicates that a country with a strong and efficient economy will have a significant influence on the country's financial market that will improve and increase the bank's profitability levels. Consequently, the findings are constant with the null hypothesis. Improvements in the country's economy will allow Islamic banks to get new investments.

In contrast, the findings of the inflation rate indicate that the inflation rate has an insignificant positive impact on the bank's profitability. Importantly, the results are identical with the findings of prior researchers, such as; Brouke (1989) and Molyneux and Thornton (1992) stated that there is a positive significant relationship between banks' profitability and inflation rate. Chiefly, when the inflation rate increases then the ability of buying power will decrease, which will lead to a gradual increase in the percentage of bank loans to the investors, and eventually will increase the Islamic bank's profitability.

\subsubsection{Conventional Banks}

The following regression represents the findings of the explanatory variable that influence the conventional banks profitability levels, by applying three different regression models: pooled effect, random effect, and fixed-effect. 
Table 6. Regression Analysis (Conventional banks)

\begin{tabular}{ccccccc}
\hline & \multicolumn{5}{c}{ Conventional Banks } \\
\hline No. abs & OLS & OLS & Random Effect & Random Effect & Fixed Effect & Fixed Effect \\
\hline R-squared & 609 & 609 & 609 & 609 & 609 & 609 \\
Adjusted R-squared & 0.809 & 0.810 & & & 0.851 & 0.852 \\
F(5, 45606) & 509.266 & 0.808 & & & 0.822 & 0.823 \\
P-value(F) & 0.000 & 0.000 & & & 78.973 & 73.893 \\
Const & 0.011 & 0.012 & 0.019 & 0.019 & 0.025 & 0.037 \\
& 0.047 & 0.078 & 0.009 & 0.029 & 0.008 & 0.011 \\
Size & -0.014 & -0.012 & -0.021 & -0.020 & -0.026 & -0.008 \\
& 0.012 & 0.079 & 0.002 & 0.036 & 0.003 & 0.671 \\
M-B-Ratio & 0.012 & 0.011 & 0.011 & 0.011 & 0.010 & 0.010 \\
Capital Ratio & 0.000 & 0.000 & 0.000 & 0.000 & 0.000 & 0.000 \\
& 0.017 & 0.018 & 0.009 & 0.010 & 0.005 & 0.007 \\
Cash/Total assets & 0.002 & 0.002 & 0.122 & 0.082 & 0.440 & 0.242 \\
GDP growth & 0.881 & 0.882 & 0.843 & 0.847 & 0.825 & 0.829 \\
Inflation & 0.000 & 0.000 & 0.000 & 0.000 & 0.000 & 0.000 \\
GDP & & 0.000 & & 0.000 & & 0.000 \\
Hausman test & & 0.326 & & 0.460 & & 0.407
\end{tabular}

The above table reveals the findings of the regression analysis for conventional banks. Also, the Hausman test results revealed significant findings, therefore the null hypothesis is rejected and the fixed effect is taken into account. In the same context, the t-test and f-test reveals that the regression model is significant at $5 \%$, the $\mathrm{R} 2$ is $(85 \%)$ and the adjusted R2 is $(82 \%)$. This means that this research determined $(85 \%)$ of the variables that have a positive or negative influence on conventional banks profitability. In other words, $(85 \%)$ of the fluctuations in the profitability levels of conventional banks occur because of changes in the explanatory factors.

The above table indicates that there is a significant negative effect of the bank size on the conventional bank's profitability levels. This indicates to the large size of assets in the conventional banks may affect the ability in managing their assets efficiently to generate profit, this is maybe because of the risky financial tools employed by conventional banks. Also, the small size of assets in the conventional banks will show better profitability levels than conventional banks with large size of assets.

However, since the sample of the study is classified into two different types of banks, the above regression findings are quite similar to the outcomes of the previous model. For instance, the results of the market to book value had a significant positive relationship with the profitability levels in the Islamic banks. In other words, an increase in the market price compared with the book value then there is a growth opportunity in the future. Also, the results of the capital ratio showed a significant positive influence on the return on assets (ROA).

Notably, both types of banks can finance their operation through the shareholder's equity. Whereby, this type of funding considered to be a quite costly and less risky funding tool, this can affect negatively the profitability level of commercial banks. Consequently, commercial banks need to increase the fund for their transaction from the 
liabilities side at a greater level than shareholders' equity, to decrease the cost average.

Markedly, the findings of the regression showed that the country's GDP and growth in GDP had a positive significant influence on Islamic banks profitability. Interestingly, this indicates that a country with a strong and efficient economy will have a significant influence on the country financial market, which will lead to improvement and increase the bank's profitability levels Moreover, the cash ratio showed a positive significant influence on the profitability levels of Islamic bank's, whereas increasing the percentage of cash to total assets will reduce the financial risks and will lead to an increase Islamic bank's profitability.

In contrast, the findings of the inflation rate indicates that there is an insignificant positive impact of the inflation rate on the Islamic bank's profitability. Chiefly, when the inflation rate increases then the ability to buy power will decrease this will lead to an increase in the percentage of bank loans to the investors, which will reflect positively on the Islamic bank's profitability.

\section{Conclusion}

The purpose of this empirical research is to increase the knowledge of this research area and propose ways to improve the profitability levels of Islamic and conventional banks. Consequently, the outcomes of this empirical study have suggested implications for policymakers, academics, and practitioners. Nevertheless, Policymakers should take into account the significance of effective internal use of the bank resources, to improve the Islamic and conventional banks' profitability.

The results of this empirical research recommend that Islamic and conventional banks should invest more in equity since these results revealed that there is a growth opportunity in the future for both the banking sector. Moreover, the empirical results recommend Islamic and conventional banks must shed the light on the process of managing their assets since the rapid growth of assets size in the Islamic and conventional banks influences their ability to manage their assets effectively. The findings of this empirical study suggest that external resources could influence strongly the Islamic and conventional banks profitability. Therefore, this empirical study recommends both kinds of banks to use external funding tools to improve their profitability levels.

Although the determinates of Islamic and conventional banks profitability are one of the significant challenges for conventional and Islamic banks. Prior studies in this arena - such as (Nurhafiza and Tajul, 2018; Heffernan and Fu 2009; Nur et al 2018; and Mohammad and Helal 2017) have not comparatively examined the profitability determinants of Islamic and conventional banks by employing a population sampling of economic and accounting data. In addition, recent previous studies in this area- such as (Harbi 2019; Hidayat \& Sakiti 2020; Imane 2020; Muhammad 2018; and Aslam \& Haron 2020) have examined particular countries or the impact of the limited number of variables such as; oil price on the banks performance, the researchers attempt to fill this gap by suggesting ways to enhance the profitability of Islamic and conventional banks by examining accounting and economic data on longitudinal data. Consequently, this research contributes to the academic literature, as the empirical results determine the external and internal variables that influence the Islamic bank's profitability.

The results of this study are subject to many limitations, the sample size of this research investigated emerging markets, this is because Islamic commercial banks are available in the MENA countries and Islamic banks still under development. In addition, this study examined the GCC region only because longitudinal data are not available in all MENA countries Also, this empirical study has shed light on one of the main challenges for both Islamic and conventional banks. Further research should concentrate on the determinants of Islamic and conventional banks' profitability. Also, more studies are required in exploring the impact of external factors and external shocks on the bank's profitability such as Arab spring, to interact with similar matters in the upcoming future.

\section{References}

Abu Hanifa, Md. N. (2015). An Empirical Investigation of Profitability of Islamic Banks in Bangladesh. Global Journal of Management and Business Research, 15(4).

Ahmad, H. (2019). The determinants of conventional banks profitability in developing and underdeveloped OIC countries. Journal of Economic, Finance and Administrative Studies, 24(47), 4-28.

Albertazzi, U., \& Gambacorta, L. (2010). Bank Profitability and Taxation. Journal of Banking and Finance, 34(11), 2801-2810.

Ali, A. (2010). Islamic Finance and Global Financial Stability. Islamic Research and Training Institute, 1-73. Retrieved from http://www.ifsb.org/docs/IFSB-IRTI-IDB2010.pdf

Ariffin, N. (2012). Liquidity risk management and financial performance in Malaysia: Empirical evidence from 
Islamic banks. International Journal of Social Science, 1(2), 68-75.

Aslam, E., Haron, R., \& Ahmad, S. (2020). A comparative analysis of the performance of Islamic and conventional banks: does corporate governance matter?. International Journal of Business Excellence, 22(3), 553-568.

Bashir, A. (2003). Determinants of profitability in Islamic banks: Some evidence from the Middle East. Islamic Economic Studies, $\quad 11(1), \quad 32-57 . \quad$ Retrieved from http://www.ues.ac.ir/files/takmili/islamic_econ./islamic_banking/vol_11_1..a_h_bashsir..determinants_of_profit ability..dp.pdf

BCBS. (2011). Operational Risk - Supervisory Guidelines for the Advanced Measurement Approaches. Basel Committee on Bank Supervision: Bank for International Settlement. Retrieved from http://www.bis.org/publ/bcbs196.pdf

Dulal Miah, Md., \& Uddin, H. (2017). Efficiency and stability: A comparative study between islamic and conventional banks in GCC countries. Future Business Journal, 3(2), 172-185. https://doi.org/10.1016/j.fbj.2017.11.001

Elsiefy, E. (2014). Fundamental Requirements for Building an Islamic Venture Capital Model. Accounting and Finance Research, 3(1), 55-66.

Gait, A., \& Worthington, A. (2008). An Empirical Survey of Individual Consumer, Business Firm and Financial Institution Attitudes towards Islamic Methods of Finance. International Journal of Social Economics, 35(11), 783-808.

Hanif, M. (2011). Differences and Similarities in Islamic and Conventional Banking. International Journal of Business and Social Science, 2(2), 165-175. $\quad$ Retrieved from http://www.ijbssnet.com/journals/Vol__2_No._2\%3B_February_2011/20.pdf

Hanif, M., \& Iqbal, A. (2010). Islamic Financing and Business Framework: A Survey. European Journal of Social Sciences, 475-489.

Hidayat, S. E., \& Sakti, M. R. P. (2020). Oil prices and Islamic banks performance in the OIC countries: evidence from the dynamic GMM approaches. Journal of Economic Cooperation \& Development, 41(2), 113-140.

IFSB. (2007). Islamic Financial Services Industry Development: Ten Year Framework and Strategies. Islamic Financial Services Board, Islamic Development Bank. Retrieved from http://www.ifsb.org/

Imane, Y. (2020). Determinants of Islamic Banks' Profitability. Roa Iktissadia Review, 10(1), 349-362.

Iqbal, M., \& Molyneux, P. (2005). Thirty Years of Islamic Banking: History, Performance and Prospects. Journal of Islamic Economics, 19(1), 37-39. Retrieved from http://kantakji.com/media/1878/9008.pdf

Iqbal, Z. (1997). Islamic Financial System. Finance and Development, 34(2), 42-45.

Khan, T., \& Ahmad, H. (2001). Risk management an analysis of issue in Islamic financial industry. Islamic development bank, Islamic research and training institute. Retrieved from http://www.sbp.org.pk/departments/ibd/Risk_Management.pdf

Kharisya, A. E., \& Disman, D. (2017) Liquidity Risk: Comparison between Islamic and Conventional Banking. European Research Studies Journal, XX(2A), 308-318.

Millar, R., \& Anwar, H. (2008). Islamic finance A Guide for International Business and Investment (1st ed.). GMB Publishing Ltd.

Mohamad, A., Mohamad, M., \& Samsudin, M. (2013). How Islamic Banks of Malaysia Managing Liquidity? An Emphasis on Confronting Economic Cycles. International Journal of Business and Social Science, 4(7).

Mohammad, T. M., Ahmad, A. S. M., \& Mohd, S. M. N. (2018). The Determinants of Bank Profitability: How Malaysian Islamic Banks Response to the Financing Risk. IJIRMPS, 6(6).

Moulyneux, P., \& Thornton, J. (1992). Determinants of European Bank Profitability: A Note. Journal of Banking and Finance, 16, 1173-1178.

Muhammad, F. S. (2018). Impact of Profitability on Market Size of Islamic Banking of Pakistan. International Journal of Accounting Research, 6(2), 181.

Muhammd, A. (2017). Determinants of Profitability of Islamic Banks of Pakistan - A Case Study on Pakistan's Islamic Banking Sector. 1st International Conference on Advances in Business, Management and Law (2017) 
Volume 2017.

Nurhafiza, A. K. M., \& Tajul, A. M. (2018). What drives bank margins during and post-crisis? A comparison between islamic and conventional banks. Asian Academy of management Journal of Accounting and Finance, 14(1), 107-126.

Okte, M. (2010). Fundamentals of Islamic Economy and Finance: Theory and Practice. Electronic Journal of Social Sciences, 9(31), 180-208.

Osama, J., Bassam, J., Jamal, S., \& Usama, F. (2017). Liquidity Risk Exposure in Islamic and Conventional Banks. International Journal of Economics and Financial Issue, 7(6), 16-26.

Pratt, J. (2010). Financial Accounting in an Economic Context (8th ed.). John Wiley \& Sons.

Samail, N. A. B., Zaidi, N. S. B., Mohamed, A. S. B., \& Kamaruzaman, M. N. B. (2018). Determinants of Financial Performance of Islamic Banking in Malaysia. International Journal of Academic Research in Accounting, Finance and Management Sciences, 8(4), 21-29.

Short, B. (1979). The relation between commercial bank profit rates and banking concentration in Canada, Western Europe and Japan. Journal of Banking and Finance, 3(3), 209-2019.

Sole, J. (2007). Introducing Islamic Banks into Conventional Banking Systems. International Monetary Fund. Retrieved from http://www.imf.org/external/pubs/ft/wp/2007/wp07175.pdf

Tariq, A. (2018). Determinants of bank profitability: Islamic versus conventional banks. Banks and Bank Systems, 13(3), 106-113.

Wilson, R. (2007). Islamic Finance in Europe. RSCAS Policy Papers. European University Institute: Florence.

Wooldridge, J. (2012). Introductory econometrics: A modern approach. Cengage Learning.

\section{Copyrights}

Copyright for this article is retained by the author(s), with first publication rights granted to the journal.

This is an open-access article distributed under the terms and conditions of the Creative Commons Attribution license (http://creativecommons.org/licenses/by/4.0/). 